\title{
Stability of Middle East respiratory syndrome coronavirus (MERS-CoV) under different environmental conditions
}

N van Doremalen ${ }^{1}$, T Bushmaker ${ }^{1}$, V J Munster (vincent.munster@nih.gov) ${ }^{1}$

1. Laboratory of Virology, Division of Intramural Research, National Institute of Allergy and Infectious Diseases, National

Institutes of Health, Hamilton, MT, USA

The stability of Middle East respiratory syndrome coronavirus (MERS-CoV) was determined at $20^{\circ} \mathrm{C}-40 \%$ relative humidity (RH); $30^{\circ} \mathrm{C}-30 \% \mathrm{RH}$ and $30^{\circ} \mathrm{C}-80 \%$ RH. MERS-CoV was more stable at low temperature/ low humidity conditions and could still be recovered after 48 hours. During aerosolisation of MERS-CoV, no decrease in stability was observed at $20^{\circ} \mathrm{C}-40 \% \mathrm{RH}$. These data suggest the potential of MERS-CoV to be transmitted via contact or fomite transmission due to prolonged environmental presence.

In 2012, a novel coronavirus termed Middle East respiratory syndrome coronavirus (MERS-CoV) emerged in the Middle East [1]. Limited human-to-human transmission of MERS-CoV has been observed [2-5] and currently no data are available on the modes of transmission. The occurrence of MERS-CoV as a respiratory pathogen and the high viral loads detected in samples from the lower respiratory tract of infected patients $[6,7]$ suggests that MERS-CoV will be predominantly shed during coughing and via exudates from the lower respiratory tract. For influenza $A$ virus it is shown that transmission is linked to the viability of the virus under different environmental conditions, such as temperature and humidity with a cool dry environment being the most favourable for transmission and either warm or humid conditions being unfavourable [8]. In this study, the stability of MERS-CoV (isolate HCoV-EMC/2012) was evaluated under three different environmental conditions: high temperature and low humidity, $30^{\circ} \mathrm{C}$ - $30 \%$ relative humidity $(\mathrm{RH})$; high temperature and high humidity, $30^{\circ} \mathrm{C}-80 \% \mathrm{RH}$ and low temperature and low humidity, $20^{\circ} \mathrm{C}-40 \% \mathrm{RH}$, to reflect a wide range of environmental conditions including an indoor environment $\left(20^{\circ} \mathrm{C}-40 \% \mathrm{RH}\right)$. The stability of MERS$\mathrm{CoV}$ under the three tested environmental conditions was respectively compared with that of influenza $A$ virus $A /$ Mexico/4108/2009 $\left(\mathrm{H}_{1} \mathrm{~N}_{1}\right)$ originating from a human isolate obtained during the influenza $A\left(\mathrm{H}_{1} \mathrm{~N}_{1}\right)$ pdmog pandemic in 2009 [9]. The stability of the two viruses in aerosols at $20^{\circ} \mathrm{C}$ with $40 \%$ or $70 \% \mathrm{RH}$ was also assessed and compared.

\section{Environmental stability}

MERS-CoV (isolate HCoV-EMC/2012) and A/ Mexico/4108/2009 $\left(\mathrm{H}_{1} \mathrm{~N}_{1}\right)$ virus were propagated and titrated by end-point titration on VeroE6 cells (for MERS-CoV) and Madin-Darby canine kidney (MDCK) cells (for A/Mexico/4108/2009 ( $\left.\mathrm{H}_{1} \mathrm{~N}_{1}\right)$ virus) as previously described $[9,10]$. To determine the environmental stability of the two viruses, $100 \mu \mathrm{l}$ of $10^{6}$ tissue culture infective dose $50\left(\mathrm{TCID}_{50}\right)$ of MERS-CoV or $\mathrm{A} /$ Mexico/4108/2009 ( $\left.\mathrm{H}_{1} \mathrm{~N}_{1}\right)$ virus was spotted in droplets of $5 \mu \mathrm{l}$ on the surface of steel or plastic washers (McMaster-Carr, USA) and incubated at the desired conditions in an environmental chamber (Caron, USA) for 10 and 30 minutes and 4, 8, 24, 48 and 72 hours. Experiments were conducted in triplicate. For both MERS-CoV and A/Mexico/4108/2009 ( $\left.\mathrm{H}_{1} \mathrm{~N}_{1}\right)$ virus, no differences in stability could be observed between the plastic and steel surface, suggesting the plastic and steel surfaces did not affect the stability differentially (Figure 1, panels A and D). MERS-CoV virus could still be recovered after 48 hours at the $20^{\circ} \mathrm{C}-$ $40 \% \mathrm{RH}$ condition, whereas for the other two conditions the virus remained viable for eight $\left(30^{\circ} \mathrm{C}-80 \%\right.$ $\mathrm{RH})$ and 24 hours $\left(30^{\circ} \mathrm{C}-30 \% \mathrm{RH}\right)$ respectively. For $\mathrm{A} /$ Mexico/4108/2009 $\left(\mathrm{H}_{1} \mathrm{~N}_{1}\right)$ virus, no virus could be recovered after four hours at each environmental condition and no difference between the environmental conditions was observed. The mean half-life values of MERS-CoV varied between 0.441822 and 0.973656 hours (five-parameter logistic model, $R$ and $R$ package drc [11]), but were not found to be significantly different (Table). Due to the rapid decrease in viability of $A$ / Mexico/4108/2009 ( $\left.\mathrm{H}_{1} \mathrm{~N}_{1}\right)$ virus, half-life values could not be calculated.

\section{Aerosol stability}

To study their respective aerosol stability, MERS-CoV and $\mathrm{A} /$ Mexico/4108/2009 $\left(\mathrm{H}_{1} \mathrm{~N}_{1}\right)$ virus were aerosolised at $20^{\circ} \mathrm{C}$ with $40 \%$ or $70 \%$ RH (Figure 2 ). Aerosol experiments were performed using the AeroMP (Biaera Technologies, USA) aerosol management platform [12]. $10^{6} \mathrm{TCID}_{50} / \mathrm{ml}$ solutions of MERS-CoV and 
Viability over time of Middle East respiratory syndrome coronavirus (MERS-CoV) and A/Mexico/4108/2009 (H1N1) virus under different environmental conditions

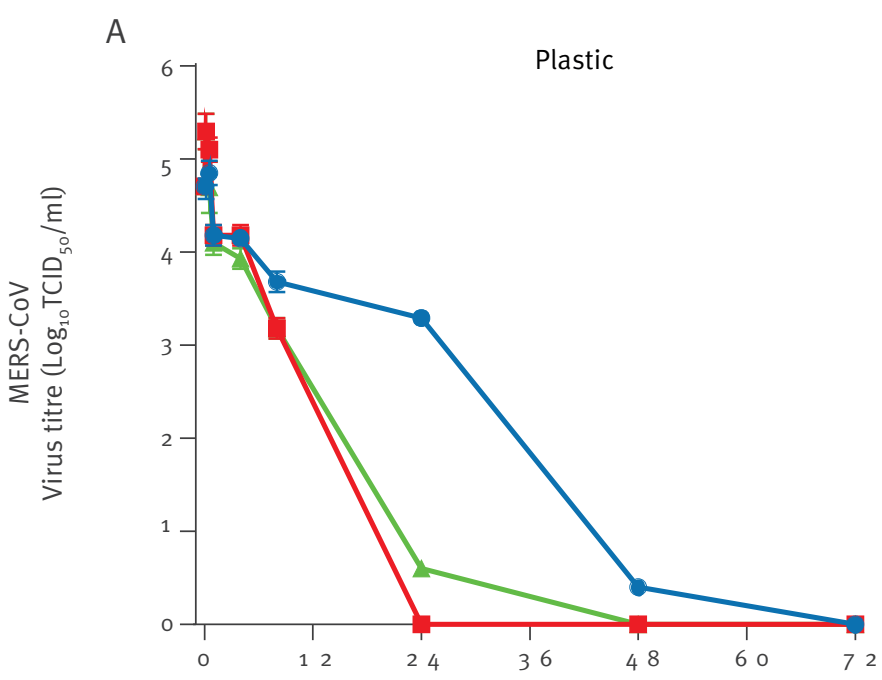

B
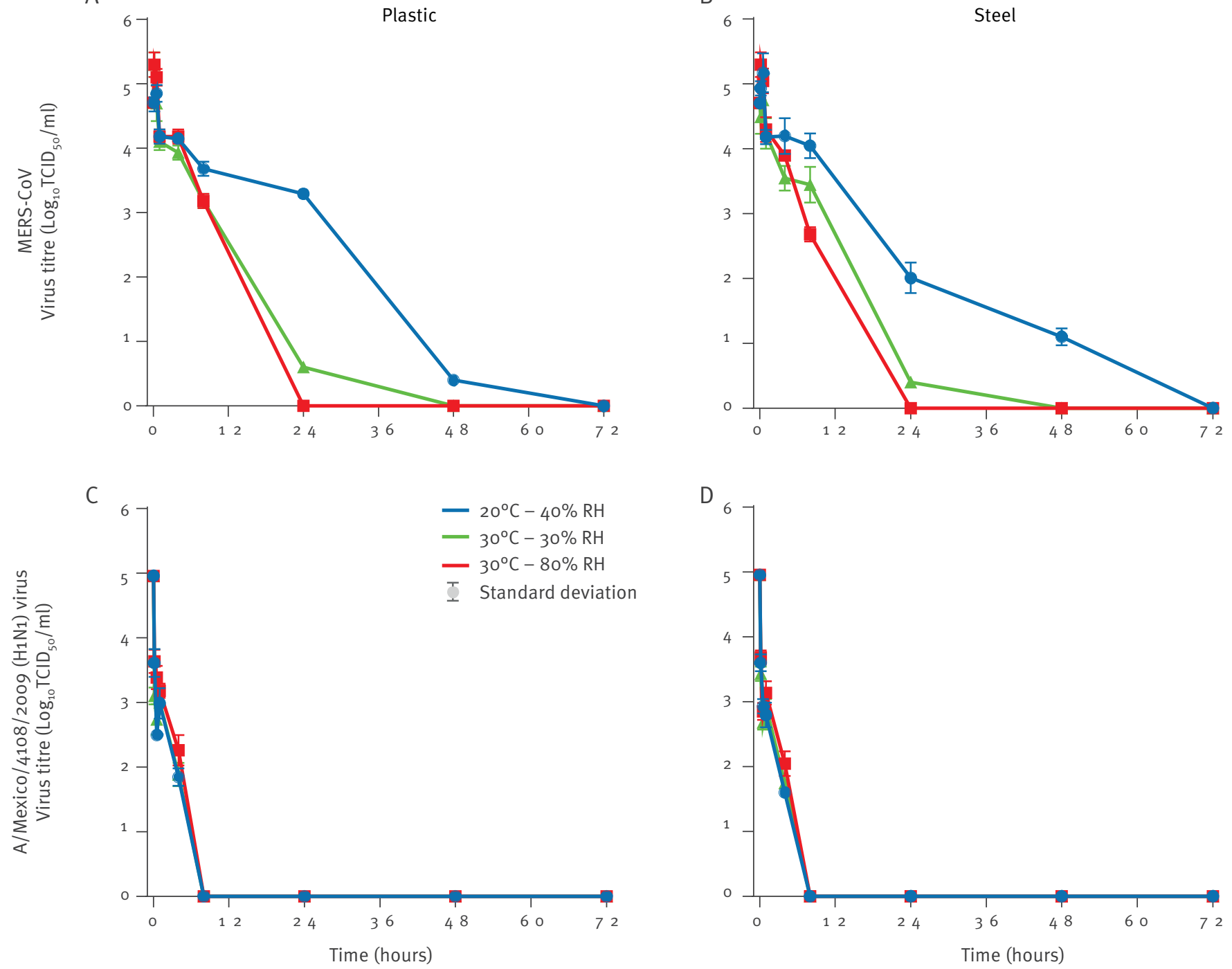

$\mathrm{RH}$ : relative humidity; $\mathrm{TCID}_{50}$ : tissue culture infective dose 50 .

$10^{6} \mathrm{TCID}_{50}$ of MERS-CoV (isolate HCoV-EMC/2012) (panels A and B) or A/Mexico/4108/2009 (H1N1) virus (panels $\mathrm{C}$ and D) was spotted on plastic (panels A and C) or steel (panels B and D) surfaces, incubated at $20^{\circ} \mathrm{C}-40 \% \mathrm{RH}$ (blue); $30^{\circ} \mathrm{C}-30 \% \mathrm{RH}$ (green) and $30^{\circ} \mathrm{C}-80 \% \mathrm{RH}$ (red) and titrated on VeroE6 cells (for MERS-CoV) or Madin-Darby canine kidney (MDCK) cells (for A/Mexico/4108/2009 (H1N1) virus).

A/Mexico/4108/2009 $\left(\mathrm{H}_{1} \mathrm{~N}_{1}\right)$ virus respectively were aerosolised in triplicate for 10 minutes. Aerosols were collected continuously during aerosolisation in tissue culture media (10 ml, DMEM) with an All Glass Impinger (Ace Glass Inc., USA). Collected aerosols were analysed by quantitative real-time polymerase chain reaction (qRT-PCR) and by virus titration $[10,13,14]$. TCID $_{50}$ equivalents were generated using a standard curve of 10 -fold diluted MERS-CoV RNA of known concentration in the qRT-PCR. Viral genomic RNA levels in TCID $_{50}$ equivalents, representative of total amount of virus particles, were compared to $\mathrm{TCID}_{50}$, representative of the amount of viable virus of either MERS-CoV or A/ Mexico/4108/2009 ( $\left.\mathrm{H}_{1} \mathrm{~N}_{1}\right)$ virus [13,14].

MERS-CoV decreased only $7 \%$ in viability at $40 \% \mathrm{RH}$, whereas the viability at $70 \% \mathrm{RH}$ decreased significantly with $89 \%$ (unpaired one-tailed Student's t-test, $\mathrm{p}=0.0045)$. The viability of $\mathrm{A} /$ Mexico/4108/2009 $\left(\mathrm{H}_{1} \mathrm{~N}_{1}\right)$ virus decreased under both conditions with $95 \%$ for $40 \% \mathrm{RH}$ and $62 \%$ for $70 \% \mathrm{RH}$ respectively. This decrease was found to be significant at $40 \% \mathrm{RH}$ $(p=0.0095)$, but not at $70 \% \mathrm{RH}$ and did not differ significantly between the two conditions. 
TABLE

Decay of Middle East respiratory syndrome coronavirus (MERS-CoV) on plastic and steel surfaces at different temperatures and percent humidity

\begin{tabular}{|l|c|c|}
\hline $\begin{array}{l}\text { Surface type; temperature, } \\
\text { relative humidity }\end{array}$ & $\begin{array}{c}\text { Mean half-life time of } \\
\text { MERS-CoV (hours) }\end{array}$ & $\begin{array}{c}\text { Standard } \\
\text { deviation }\end{array}$ \\
\hline Plastic; $20^{\circ} \mathrm{C}, 40 \%$ & 0.954523 & 1.110443 \\
\hline Plastic; $30^{\circ} \mathrm{C}, 30 \%$ & 0.441822 & 0.345291 \\
\hline Plastic; $30^{\circ} \mathrm{C}, 80 \%$ & 0.904005 & 4.6838 \\
\hline Steel; $20^{\circ} \mathrm{C}, 40 \%$ & 0.940139 & 1.837771 \\
\hline Steel; $30^{\circ} \mathrm{C}, 30 \%$ & 0.973656 & 0.31109 \\
\hline Steel; $30^{\circ} \mathrm{C}, 80 \%$ & 0.641163 & 0.825395 \\
\hline
\end{tabular}

Mean half-life was determined from three independent experiments.

\section{Discussion}

Since MERS-CoV emerged [1], an increasing number of human cases have been identified in eight different countries with a case-fatality rate of $50-$ to $60 \%$ [15]. Small clusters of cases with human-to-human transmission have occurred in the United Kingdom, France and Italy. In these clusters, initial cases had a recent travel history to the Middle East and subsequently infected secondary cases [2-5]. In addition, the largest cluster with suspected human-to-human transmission of MERS-CoV has been observed in Saudi Arabia and is epidemiologically linked to healthcare facilities, suggesting nosocomial transmission [16]. The recent identification of the potential circulation of MERS-CoV in dromedary camels could indicate that both zoonotic and human-to-human transmission is involved in the ongoing spread of MERS-CoV $[17,18]$.

Here we show that compared to A/Mexico/4108/2009 $\left(\mathrm{H}_{1} \mathrm{~N}_{1}\right)$ virus, MERS-CoV remains viable for a longer duration in the environment. After four hours no viable $\mathrm{A} / \mathrm{Mexic0} / 4108 / 2009$ ( $\left.\mathrm{H}_{1} \mathrm{~N}_{1}\right)$ virus was detected in comparison to 8,24 or 48 hours for MERS-CoV depending on environmental conditions (Figure 1, panels $A$ and D). MERS-CoV was very stable in aerosol form at $20^{\circ} \mathrm{C}-$ $40 \% \mathrm{RH}$. The decrease in viability at $20^{\circ} \mathrm{C}-70 \% \mathrm{RH}$ (89\%) was comparable to that of $A / M e x i c o / 4108 / 2009$ $\left(\mathrm{H}_{1} \mathrm{~N}_{1}\right)$ virus. Severe acute respiratory syndrome coronavirus (SARS-CoV) has been reported to stay viable for up to five days at 22 to $25^{\circ} \mathrm{C}$ and 40 to $50 \% \mathrm{RH}$ and increase in temperature and humidity resulted in a rapid loss of viability [19]. Although a comparison between different experimental studies should be approached cautiously, the relative stability of MERS$\mathrm{CoV}$ at $20^{\circ} \mathrm{C}-40 \% \mathrm{RH}$ and the rapid decrease in virus viability at higher temperatures and higher humidity suggests that MERS-CoV and SARS-CoV share relatively similar stability characteristics. Although the route of transmission for MERS-CoV is currently unknown, the spread of MERS-CoV between people in close contact

\section{FIGURE 2}

Aerosol stability of Middle East respiratory syndrome coronavirus (MERS-CoV) and A/Mexico/4108/2009

(H1N1) virus under different relative humidity conditions*

A

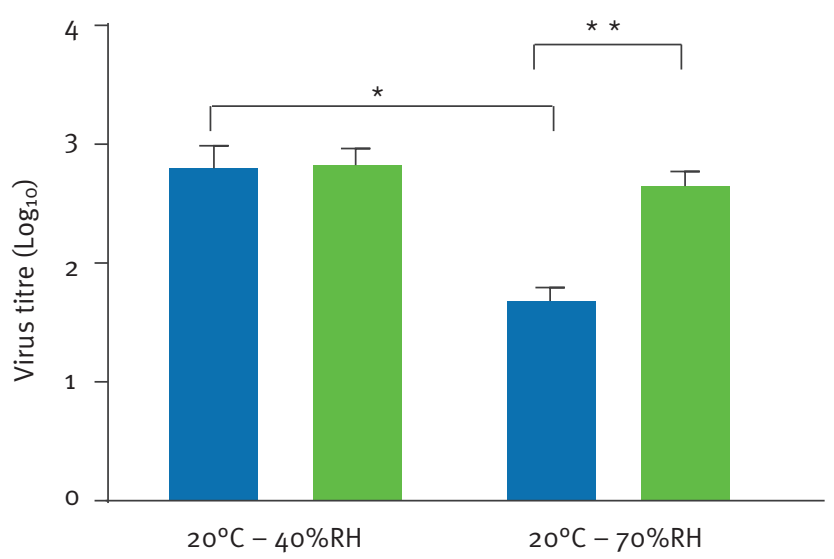

B

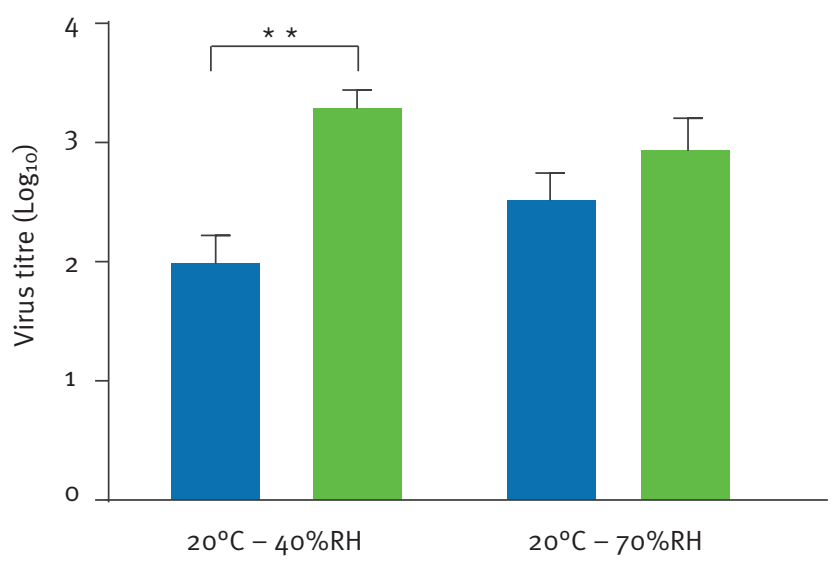

Virus titre in $\log _{10} T C D_{50} / \mathrm{ml}$
Virus genome copies $\log _{10} T C D_{50}$ equivalents $/ \mathrm{ml}$

Error bars represent standard deviation.

${ }^{*}=p$-value $<0.05 ;{ }^{* *}=p$-value $<0.01$

$\mathrm{TCID}_{50}$ : tissue culture infective dose 50.

$10^{6} \mathrm{TCID} 50 / \mathrm{ml}$ of MERS-CoV (panel A) and A/Mexico/4108/2009 $\left(\mathrm{H}_{1} \mathrm{~N}_{1}\right)$ (panel B) were aerosolised and viability was determined by titration on VeroE6 cells (for MERS-CoV) or Madin-Darby canine kidney (MDCK) cells (for A/Mexico/4108/2009 (H1N1) virus), and compared to $\mathrm{TCID}_{50}$ equivalents derived by quantitative real-time polymerase chain reaction ( $q R T-P C R)$.

$\mathrm{TCID}_{50}$ equivalents were extrapolated from standard curves generated by adding dilutions of RNA extracted from a MERS-CoV stock with known virus titre in parallel to each run. 
settings suggest contact and fomite transmission routes are most likely involved [2,3,16]. Knowledge on the environmental stability of MERS-CoV does not provide direct insights in the route of transmission; yet it does provide us with a better understanding for the potential of aerosol, contact and fomite transmission. The prolonged survival of MERS-CoV compared to A/ Mexico/4108/2009 $\left(\mathrm{H}_{1} \mathrm{~N}_{1}\right)$ virus on surfaces increases the likelihood of contact and fomite transmission. However, the decrease in viability observed at high temperature suggests that direct contact transmission, and not fomite transmission, in the Arabian Peninsula would be the most likely route of zoonotic and humanto-human transmission in outdoor settings. The ability of MERS-CoV to remain viable in an airborne state suggests the potential for MERS-CoV to acquire the ability to be transmitted via aerosols. In the absence of therapeutic and prophylactic intervention strategies for MERS-CoV, a thorough understanding of the routes of transmission could be the most effective way to arrest the further spread of MERS-CoV.

\section{Acknowledgements}

The authors would like to thank Drs. Bart Haagmans and Ron Fouchier, Erasmus Medical Center, Rotterdam, The Netherlands for providing MERS-CoV (isolate HCoVEMC/2012), Emmie de Wit and Matt Lackemeyer for excellent technical assistance and helpful discussions, Anita Mora for assistance with the figures and Kui Shen for assistance with statistical analyses. This research was supported by the Intramural Research Program of the National Institute of Allergy and Infectious Diseases (NIAID), National Institutes of Health (NIH).

\section{Conflict of interest}

None declared.

\section{Authors' contributions}

N.v.D. and V.J.M. conceived and designed the study, N.v.D. and T.B. performed the experiments, N.v.D. and V.J.M. analysed the data, N.v.D. and V.J.M wrote the manuscript.

\section{${ }^{*}$ Erratum}

Figure 2 was corrected and replaced on 23 September 2013.

\section{References}

1. Zaki AM, van Boheemen S, Bestebroer TM, Osterhaus AD, Fouchier RA. Isolation of a novel coronavirus from a man with pneumonia in Saudi Arabia. N Engl J Med. 2012;367(19):181420. http://dx.doi.org/10.1056/NEJMoa1211721. PMid:23075143.

2. Mailles A, Blanckaert K, Chaud P, van der Werf S, Lina B, Caro V, et al. First cases of Middle East Respiratory Syndrome Coronavirus (MERS-CoV) infections in France, investigations and implications for the prevention of humanto-human transmission, France, May 2013. Euro Surveill. 2013;18(24):pii=20502. Available from: http://www. eurosurveillance.org/ViewArticle.aspx?Articleld=20502 PMid:23787161

3. The Health Protection Agency (HPA) UK Novel Coronavirus Investigation team. Evidence of person-to-person transmission within a family cluster of novel coronavirus infections, United Kingdom, February 2013 . Euro Surveill. 2013;18(11): pii=20427.
Available from: http://www.eurosurveillance.org/ViewArticle. aspx?Articleld $=20427$

4. Bermingham A, Chand MA, Brown CS, Aarons E, Tong C, Langrish C, et al. Severe respiratory illness caused by a novel coronavirus, in a patient transferred to the United Kingdom from the Middle East, September 2012. Euro Surveill. 2012;17(40): pii=20290. Available from: http://www. eurosurveillance.org/ViewArticle.aspx?Articleld=20290

5. Puzelli S, Azzi A, Santini MG, Di Martino A, Facchini M, Castrucci MR, et al. Investigation of an imported case of Middle East Respiratory Syndrome Coronavirus (MERSCoV) infection in Florence, Italy, May to June 2013. Euro Surveill. 2013;18(34): pii=20564. Available from: http://www. eurosurveillance.org/ViewArticle.aspx?Articleld $=20564$. PMid:23987829.

6. Drosten C, Seilmaier M, Corman VM, Hartmann W, Scheible $\mathrm{G}$, Sack S, et al. Clinical features and virological analysis of a case of Middle East respiratory syndrome coronavirus infection. Lancet Infect Dis. 2013;13(9):745-51. http://dx.doi.org/10.1016/S1473-3099(13)70154-3

7. Guery B, Poissy J, el Mansouf L, Séjourné C, Ettahar N, Lemaire X, et al. Clinical features and viral diagnosis of two cases of infection with Middle East Respiratory Syndrome coronavirus: a report of nosocomial transmission. Lancet. 2013;381(9885):2265-72. http://dx.doi.org/10.1016/S0140-6736(13)60982-4

8. Steel J, Palese P, Lowen AC. Transmission of a 2009 pandemic influenza virus shows a sensitivity to temperature and humidity similar to that of an $\mathrm{H}_{3} \mathrm{~N}_{2}$ seasonal strain. J Virol. 2011;85(3):1400-2. http://dx.doi.org/10.1128/JVI.02186-10. PMid:21084485. PMCid:PMC3020521.

9. Safronetz D, Rockx B, Feldmann F, Belisle SE, Palermo RE Brining D, et al. Pandemic swine-origin $\mathrm{H}_{1} \mathrm{~N}_{1}$ influenza $A$ virus isolates show heterogeneous virulence in macaques. J Virol. 2011;85(3):1214-23.

http://dx.doi.org/10.1128/JVI.01848-10. PMid:21084481. PMCid:PMC3020514.

10. de Wit E, Prescott J, Baseler L, Bushmaker T, Thomas T, Lackemeyer MG, et al. The Middle East respiratory syndrome coronavirus (MERS-CoV) does not replicate in Syrian hamsters. PLoS One. 2013;8(7): e69127. http://dx.doi.org/10.1371/ journal.pone.0069127 PMid:23844250. PMCid:PMC3699510.

11. Ritz C, Streibig JC. Bioassay analysis using R. Journal of Statistical Software. 2005;12(5):1-22.

12. Hartings JM, Roy CJ. The automated bioaerosol exposure system: preclinical platform development and a respiratory dosimetry application with nonhuman primates. J Pharmacol Toxicol Methods. 2004;49(1): 39-55.

http://dx.doi.org/10.1016/j.vascn.2003.07.001 PMid:14670693.

13. Corman VM, Eckerle I, Bleicker T, Zaki A, Landt O, Eschbach Bludau M, et al. Detection of a novel human coronavirus by real-time reverse-transcription polymerase chain reaction. Euro Surveill. 2012;17(39):pii=20285. Available from: http:// www.eurosurveillance.org/ViewArticle.aspx?Articleld $=20285$

14. Munster VJ, Baas C, Lexmond P, Bestebroer TM, Guldemeester J, Beyer WE, et al. Practical Considerations for High-Throughput Influenza A Virus Surveillance Studies of Wild Birds by Use of Molecular Diagnostic Tests. J Clin Microbiol. 2009;47(3):66673 http://dx.doi.org/10.1128/JCM.01625-08. PMid:19109483. PMCid:PMC2650931.

15. World Health Organization (WHO). Global Alert and Response (GAR). Coronavirus infections. [Accessed 19 Sep 2013]. Available from: http://www.who.int/csr/don/archive/disease/ coronavirus_infections/en/index.html

16. Assiri A, McGeer A, Perl TM, Price CS, Al Rabeeah AA, Cummings DA, et al. Hospital Outbreak of Middle East Respiratory Syndrome Coronavirus. N Engl J Med. 2013;369(5):407-16. http://dx.doi.org/10.1056/ NEJMoa1306742. PMid:23782161.

17. Perera RA, Wang P, Gomaa MR, El-Shesheny R, Kandeil A, Bagato O, et al. Seroepidemiology for MERS coronavirus using microneutralisation and pseudoparticle virus neutralisation assays reveal a high prevalence of antibody in dromedary camels in Egypt, June 2013. Euro Surveill. 2013;18(36): $\mathrm{pii}=20574$. Available from: http://www. eurosurveillance.org/ViewArticle.aspx?Articleld $=20574$

18. Reusken CB, Haagmans BL, Müller MA, Gutierrez C, Godeke GJ, Meyer $\mathrm{B}$, et al. Middle East respiratory syndrome coronavirus neutralising serum antibodies in dromedary camels: a comparative serological study. Lancet Infect Dis. 8 Aug 2013. [Epub ahead of print].

19. Chan KH, Peiris JS, Lam SY, Poon LL, Yuen KY, Seto WH. The Effects of Temperature and Relative Humidity on the Viability of the SARS Coronavirus. Adv Virol. 2011;2011:734690. 